\title{
Mosquitoes Breeding Potentials of Dumpsites in Selected Location in Uyo Local Government Area of Akwa Ibom State, Nigeria
}

\author{
Afia U. U*, EFIONG E. EDET \\ Department of Zoology, University of Uyo, Uyo, Akwa Ibom State, Nigeria \\ *Corresponding author: afia_udeme@yahoo.com
}

\begin{abstract}
A survey on Mosquitoe breeding potentials of dumpsites in selected locations in Uyo Local Government Area, Akwa Ibom State, Nigeria was carried out between October and November, 2015. Samples were collected in both stagnant waterand containerof domestic dumping site, Dumping site in Mechanical village, and Industrial site. A total of 1648 specimen of mosquitoes larvae from three genuses (Anopheles, culex, and Aedes) were encountered. 1318 larvae found in stagnant water, while 330 recovered from container of water.In stagnant water, the following result were obtain; domestic dumping site; culex spp. 310 (44\%) >Anopheles spp. 218 (30\%)>Aedes Spp. 184(26\%) Mechanical village dumping site: Anopheles $210(44 \%)>$ Aedes 141 (30\%)>Culex Spp.. 121 (26\%0 and industrial dumping site; Culex 57 (43\%)>Anopheles Spp. 42 (31\%)>Aedes Spp. 35 (26). Induced container the following result was obtained, domestic dumping site; Culex spp. 95 (51\%)> Anopheles pp. 69(37\%)> Aedes spp. 22(12\%), mechanic village dumping site: Anopheles spp. 57 (64\%)> Culex Spp. 23 (26\%)> Aedes Spp. 9 (10\%) and industrial dumping site: culux spp. 40 (73\%)> Anopheles Spp. 10(18\%)>AedesSpp. 5 (9\%). Culex Spp. was observed to be dominant in domestic and industrial dumping site, Anopheles Spp.was observed to be dominant in mechanic village dumping site while Aedes Spp. was observed to be the least dominant in the three selected sampling area. The ratio of male to female in the three sampling area was 1:2. In conclusion, the occurrence of Anopheles Spp, Aedes Spp. and culex Spp. in the study area indicates high risk of vector borne diseases such as malaria, yellow fever, dengue fever and filariasis.
\end{abstract}

Keywords: mosquitoe, dumping site, potential, breeding

Cite This Article: Afia U. U, and EFIONG E. EDET, "Mosquitoes Breeding Potentials of Dumpsites in Selected Location in Uyo Local Government Area of Akwa Ibom State, Nigeria." American Journal of Zoological Research, vol. 5, no. 1 (2017): 5-12. doi: 10.12691/ajzr-5-1-2.

\section{Introduction}

The ecological basis for disease dates at least as far back as $400 \mathrm{BC}$ to Hippocrates's writing on Air, water and place. As Wilson [38] clarifies, our understanding and therefore control of diseases is inadequate without "ecological" perspective on the life cycles of parasitic micro-organism and the associated infectious diseases. "Many of the critical health problems in the world today cannot be solved without major improvement in environmental quality" [34].

Transmission and control of malaria has clear links to ecosystem changes that result from natural resources policies. The resulting ecosystem change has a tremendous influence on the pattern of diseases such as malaria $[16,21,25,27,28]$, this is partly because of all the forest species that transmit disease to human beings, Mosquitoes are among the most sensitive to ecosystem changes; their survival, density and distribution have been altered by environmental changes caused by different land transformation [27,28].

Tropical diseases such as dengue fever, lymphatic filariasis, malaria, yellow fever and those caused by the
West Nile virus and other viruses are all transmitted by mosquitoes [5]. Malaria is the most common and important parasitic disease transmitted by mosquitoes. It is transmitted through the bite of an infected female Anopheles mosquito. The most important species of malaria parasite involved are plasmodium falciparum, $P$. Ovale, P. malariae, P. knowlesi, P. vivax (Midegu 2006; Umar, 2014). Diseases transmitted by mosquitoes have been responsible for killing more than all the wars in history (Beerntsen, 2000; Umar, 2014).

Vector control is of great importance in combating malaria. Since the year 2000, the World Health Organization (WHO) embraced vector control as a major tool for combating malaria. This has been done by financially facilitating increased availability of insecticide treated bed nets 3\% to 50\% by the year 2011 and increased indoor residual spraying (IRS) from 5\% to $11 \%$ by the year 2010 in sub-Saharan Africa (WHO, 2011). This show that in Nigeria and other sub-Saharan African countries where malaria is endemic, there have been massive investment toward provision and access to Artemisinin based Combination Therapies (ACTs) and effort have been made largely towards adult mosquito 
control. Adult mosquito control has been achieved using ITNs and IRS, which both use chemical insecticides. In contrast there has been little adoption of larval control strategies (Afia and Mbang, 2014).

In 1939, Dichlorodiphenyltrichoroethene (DDT) and other conventional insecticides were discovered leading to a neglect of the biological methods of control because of their effectiveness in killing insect pests such as mosquitoes. Consequently, Kwanboka, (2014) brought to the attention of the world that the continued indiscriminate use of chemical insecticides has harmful effect to the environment. Due to these concerns, it has become necessary to find new interventional use of chemical insecticides.

There is renewed interest in the use of biological control method such as the use of bacteria like Bacillus Sphaericus (Bs), Bacillus thuringiensis var Israelensis (Bti), the use of fungus as well as predators and competitors (here after termed controphic species of the mosquito larvae). These control method target the larval stages of mosquito vector (Blausten and Chase, 2007; Becker et al, 2010; Mwangangi et al, 2011; Schotte et al; 2004; Kwamboka, 2014).

Controphic species may play a major role in reducing mosquito larval population. The mosquito life cycle exist in four stages of egg, larva, pupa and adult. The first three stages are aquatic thus living an opportunity for larval control. A large number of invertebrate taxa share the same larval habitats as mosquitoes and interact with their larvae through predation, competition and mutualism (Duquesne et al; 2011; Elono et al; 2010; Kwamboka, 2014). These invertebrate taxa are generally found in the phylum arthropods with exception such as the Anuran larvae and the mullusca.

The Arthropods include the larvae of Diptera Coleoptera, Hemiptera, Zygoptera, Hydrachnidiae, Anisoptera and Crustaceans among other members of these invertebrate taxa have been shown to influence the fitness of mosquito larvae by increasing mortality of immature stages of the mosquito through prolonged development time and reducing the number of offspring by causing delayed reproduction and law fecundity in the adults (Fisher et al; 2012; Kwamboka, 2014). The interaction between mosquito larvae and Anuran larvae (tadpoles of frogs and toads) had also received a great deal of attention (Blaustein and Margulit, 1994; Mokang and shine, 2002; Kwamboka, 2014). One advantage of using predator is that they can reach mosquito larvae in some habitats such as holes (Phytotelmata) and other water bodies that are difficult to reach using other biological measures as larvicides (Shalaan and Canyon, 2009; Kwamboka, 2014). Therefore controphic species are potential biological control method of the Anopheles mosquito larvae, and ecological approach toward malaria control.

\section{Materials and Methods}

\subsection{Study Area}

The study was carried out within Uyo metropolis Akwa Ibom State in the South Southern part of Nigeria between
October and November, 2015. The state is one of the fastest growing regions in Nigeria with a rapid increase in human population due to urbanization and industrialization.

Three sampling sites (Domestic dumping sites, mechanic village dumping site and industrial dumping sites) were carefully selected from three different locations within the Uyo municipality with the following coordinates: Latitude 5.04088Nand longitude 7.92379E, latitude 5.02492N and longitude 7.899452E and latitude $5.14554 \mathrm{~N}$ and longitude $7.88431 \mathrm{E}$ respectively. However, the sampling sites lack good modern waste management facilities as a result of this, waste are often being disposed in the open environment.

\subsection{Sample Collection}

In the natural environment, stagnant water were found in empty containers and vessels in the various dumping sites. Within these pools of stagnant water, larvae of mosquitoes were freely swimming to the water top to trap oxygen. These larvae were collected with the use of sieve container with mesh size $55 \mathrm{~mm}$ and preserved in a container to the laboratory for counting and identification.

Induced container were filled with water and keep in different sampling sites for a period of 7 days, thereafter it was covered with a net then taken to the laboratory for sorting, counting and identification.

\subsection{Identification of Mosquito Specimen}

All the samples collected across the three sampling sites in both the natural and induced habitat were identified with the use of field microscope and mosquito identification guides in the University of Uyo Zoology laboratory such as provided by UNCEF, (2000).

\subsection{Data Analysis}

The data obtained during the course of study were analyzed by simple averages, mosquito genus, and sex.

\section{Results}

The results of mosquitoe breeding site in selected areas in Uyo Local Government is presented in the table as follows:

A total of 1,648 specimen of mosquitoe larvae from 3 genera (Anopheles, culex and Aedes) were encountered during the study period. 1,318 larvae found in the sampling sites (Stagnant water), while 330 larvae were recovered from the human induced container. The distributions of mosquitoe were recorded from three sampling sites (Domestic dumping site, mechanic dumping site and industrial dumping site) and the results were given as follows:

In the Stagnant water, the distribution of mosquito; larvae across the different sampling sites were as follows; Domestic dumping site 712 (54\%) > mechanic dumping site $472(36 \%)>$ industrial dumping site 134 (10\%). Within the domestic dumping site, the distribution and prevalence of mosquitoe larvae were observed in the following order; Culex Spp. 310 (44\%) >Anopheles Spp. 218 (30\%) >Aedes Spp. 184 (26\%). 
In the mechanic dumping site, the order of prevalence included; Anopheles 210 (44\%) >Aedes spp. 141 (30\%) >Culex Spp. 121 (26\%). In the industrial dumping site the order of prevalence was as follows; Culex 57 (43\%) >Anopheles Spp. 42 (31\%) >Aedes Spp. 35 (26\%).

Culex Spp. Was observed to have a higher prevalence of 310 (23\%) a value which was recorded in the domestic dumping site; while Aedes had a lower prevalence of 35 (3\%) which was observed in the industrial dumping site.

In the human induced container, the distribution and prevalence was observed as follows: Domestic dumping site $186(56 \%)>$ mechanic dumping site 89 (27\%) > industrial dumping site 55 (17\%).

In the domestic dumping site, the following order of prevalence and distribution were observed Culex spp. 95 (51\%) >Anopheles spp. 69 (37\%) >Aede spp. 22 (12\%). In the mechanic dumping site, the following order was observed Anopheles 57 (64\%) >Culex 23 (26\%) >Aedes spp $9(10 \%)$. In the industrial dumping site, the order was also observed Culex 40 (73\%) >Anopheles spp 10(18\%) >Aedes spp. 5 (9\%).

In the human induced container, Culex spp. was also observed to have the highest prevalence and distribution of 95 (29\%) while Aedes spp was observed to have the lowest prevalence of 5 (2\%) recorded in industrial dumping site.

Generally, with the stagnant water and human induced container across the three sampling sites, the ration of male to female larvae were $1: 2$.

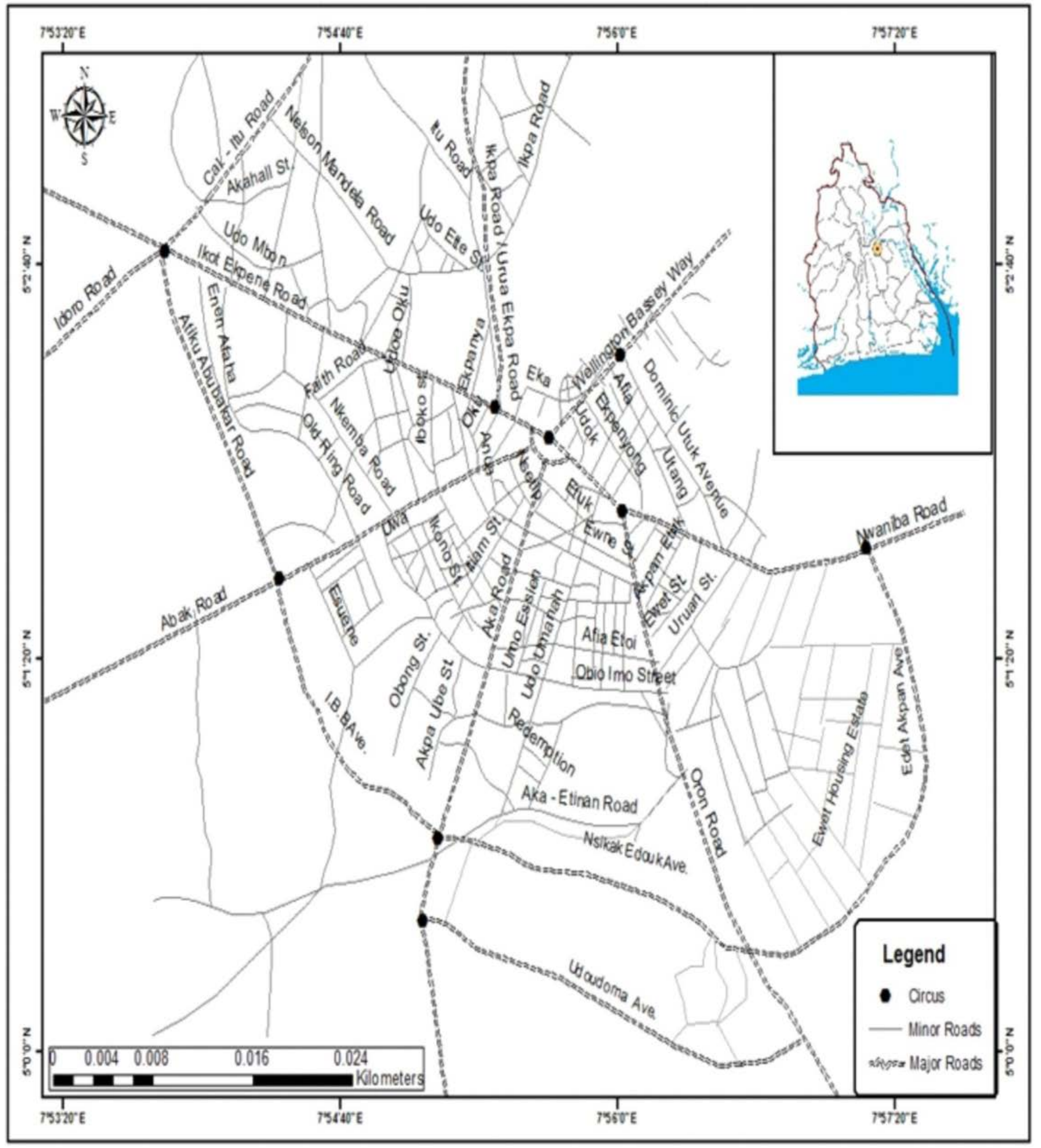

Plate 1. Map of study area (UYO LOCAL GOVERNMENT AREA) 
Table 1. A tableshowing the total number of mosquitoes encounteredand their sex composition at the domestic dumping site

\begin{tabular}{|c|c|c|c|c|c|c|c|}
\hline $\mathrm{S} / \mathbf{N}$ & Mosquitoe Spp. & Sex & Stagnant water & Total & Induce container & Total & Grand Total \\
\hline 1 & \multirow{2}{*}{ Anopheles Spp. } & Male & 90 & \multirow{2}{*}{218} & 28 & \multirow[t]{2}{*}{69} & \multirow{2}{*}{287} \\
\hline & & Female & 128 & & 41 & & \\
\hline 2 & \multirow{2}{*}{ Culex Spp. } & Male & 120 & \multirow{2}{*}{310} & 26 & \multirow{2}{*}{95} & \multirow{2}{*}{405} \\
\hline & & Female & 190 & & 69 & & \\
\hline 3 & \multirow{2}{*}{ Aedes Spp. } & Male & 78 & \multirow{2}{*}{184} & 9 & \multirow{2}{*}{22} & \multirow{2}{*}{206} \\
\hline & & Female & 106 & & 13 & & \\
\hline & \multirow{2}{*}{ Total } & Male & & \multirow{2}{*}{712} & & \multirow{2}{*}{186} & \multirow{2}{*}{898} \\
\hline & & Female & & & & & \\
\hline
\end{tabular}

Table 2. A table showing total number of mosquitoes encountered and sex variation dumping site in mechanic village

\begin{tabular}{|c|c|c|c|c|c|c|c|}
\hline $\mathrm{S} / \mathrm{N}$ & Mosquitoe Spp. & Sex & Stagnant water & Total & Induce container & Total & Grand Total \\
\hline 1 & \multirow{2}{*}{ Anopheles Spp. } & Male & 84 & \multirow{2}{*}{210} & 10 & \multirow{2}{*}{57} & \multirow{2}{*}{267} \\
\hline & & Female & 126 & & 47 & & \\
\hline 2 & \multirow{2}{*}{ Culex Spp. } & Male & 31 & \multirow{2}{*}{121} & 2 & \multirow{2}{*}{23} & \multirow{2}{*}{144} \\
\hline & & Female & 90 & & 21 & & \\
\hline 3 & \multirow{2}{*}{ Aedes Spp. } & Male & 55 & \multirow{2}{*}{141} & 2 & \multirow{2}{*}{9} & \multirow{2}{*}{150} \\
\hline & & Female & 86 & & 7 & & \\
\hline & \multirow{2}{*}{ Total } & Male & & \multirow{2}{*}{472} & & \multirow{2}{*}{89} & \multirow{2}{*}{561} \\
\hline & & Female & & & & & \\
\hline
\end{tabular}

Table 3. A table showing total number of mosquitoes encountered and sex variation at industrial dumping site

\begin{tabular}{|c|c|c|c|c|c|c|c|}
\hline S/N & Mosquitoe Spp. & Sex & Stagnant water & Total & Induce container & Total & Grand Total \\
\hline 1 & \multirow{2}{*}{ Anopheles Spp. } & Male & 20 & \multirow{2}{*}{42} & 1 & \multirow{2}{*}{10} & \multirow{2}{*}{52} \\
\hline & & Female & 22 & & 9 & & \\
\hline 2 & \multirow{2}{*}{ Culex Spp. } & Male & 23 & \multirow{2}{*}{57} & 5 & \multirow{2}{*}{40} & \multirow{2}{*}{97} \\
\hline & & Female & 34 & & 35 & & \\
\hline 3 & \multirow{2}{*}{ Aedes Spp. } & Male & 9 & \multirow{2}{*}{55} & 1 & \multirow{2}{*}{5} & \multirow{2}{*}{60} \\
\hline & & Female & 26 & & 4 & & \\
\hline & \multirow{2}{*}{ Total } & Male & & \multirow{2}{*}{154} & & \multirow{2}{*}{55} & \multirow{2}{*}{209} \\
\hline & & Female & & & & & \\
\hline
\end{tabular}

Table 4. A table showing the numbers of mosquitoes, their sex variation and theirgenera in stagnant water

\begin{tabular}{|c|c|c|c|c|c|c|c|c|c|c|}
\hline $\mathrm{S} / \mathrm{N}$ & $\begin{array}{l}\text { Mosquitoe } \\
\text { Spp. }\end{array}$ & Sex & $\begin{array}{c}\text { Domestic } \\
\text { Dumping Site }\end{array}$ & Total & $\begin{array}{c}\text { Mechanic } \\
\text { Dumping } \\
\text { Site }\end{array}$ & Total & $\begin{array}{c}\text { Industrial } \\
\text { Dumping Site }\end{array}$ & Total & $\begin{array}{l}\text { Grand } \\
\text { Total }\end{array}$ & $\begin{array}{c}\text { Grand } \\
\text { Total of } \\
\text { Sex } \\
\end{array}$ \\
\hline \multirow[t]{2}{*}{1} & \multirow{2}{*}{ Anopheles Spp } & Male & 90 & \multirow{2}{*}{$\begin{array}{c}218 \\
(30 \%)\end{array}$} & 84 & \multirow{2}{*}{$\begin{array}{c}210 \\
(44 \%)\end{array}$} & 20 & \multirow{2}{*}{$\begin{array}{c}42 \\
(31 \%)\end{array}$} & \multirow{2}{*}{470} & 194 (41\%) \\
\hline & & Female & 128 & & 126 & & 22 & & & 276 (59\%) \\
\hline \multirow[t]{2}{*}{2} & \multirow{2}{*}{ Culex Spp. } & Male & 120 & \multirow{2}{*}{$\begin{array}{c}310 \\
(44 \%)\end{array}$} & 31 & \multirow{2}{*}{$\begin{array}{c}121 \\
(26 \%)\end{array}$} & 23 & \multirow{2}{*}{$\begin{array}{c}57 \\
(43 \%)\end{array}$} & \multirow{2}{*}{488} & 174 (36\%) \\
\hline & & Female & 190 & & 90 & & 34 & & & 314 (64\%) \\
\hline \multirow[t]{4}{*}{3} & \multirow{2}{*}{ Aedes Spp. } & Male & 78 & \multirow{2}{*}{$\begin{array}{c}184 \\
(26 \%)\end{array}$} & 55 & \multirow{2}{*}{$\begin{array}{c}141 \\
(30 \%)\end{array}$} & 9 & \multirow{2}{*}{$\begin{array}{c}35 \\
(26 \%)\end{array}$} & \multirow{2}{*}{360} & 142 (39\%) \\
\hline & & Female & 106 & & 86 & & 26 & & & 218 (61\%) \\
\hline & \multirow{2}{*}{ Total } & Male & 288 & \multirow{2}{*}{$\begin{array}{c}712 \\
(54 \%)\end{array}$} & 195 & \multirow{2}{*}{$\begin{array}{c}472 \\
(36 \%)\end{array}$} & 52 & \multirow{2}{*}{$\begin{array}{c}134 \\
(10 \%)\end{array}$} & \multirow{2}{*}{1318} & 510 (39\%) \\
\hline & & Female & 424 & & 328 & & 82 & & & 808 (61\%) \\
\hline
\end{tabular}

Table 5. A table showing the numbers of mosquitoes, their sex variation and their genera ininduced container

\begin{tabular}{|c|c|c|c|c|c|c|c|c|c|c|}
\hline $\mathbf{S} / \mathbf{N}$ & $\begin{array}{c}\text { Mosquitoe } \\
\text { Spp. }\end{array}$ & Sex & $\begin{array}{c}\text { Domestic } \\
\text { Dumping Site }\end{array}$ & Total & $\begin{array}{c}\text { Mechanic } \\
\text { Dumping } \\
\text { Site }\end{array}$ & Total & $\begin{array}{c}\text { Industrial } \\
\text { Dumping Site }\end{array}$ & Total & $\begin{array}{l}\text { Grand } \\
\text { Total }\end{array}$ & $\begin{array}{c}\text { Grand } \\
\text { total of sex }\end{array}$ \\
\hline \multirow[t]{2}{*}{1} & \multirow{2}{*}{ Anopheles Spp } & Male & 28 & \multirow{2}{*}{$\begin{array}{c}69 \\
(37 \%) \\
\end{array}$} & 10 & \multirow{2}{*}{$\begin{array}{c}57 \\
(64 \%) \\
\end{array}$} & 1 & \multirow{2}{*}{$\begin{array}{c}10 \\
(18 \%)\end{array}$} & \multirow{2}{*}{$\begin{array}{c}136 \\
(41 \%)\end{array}$} & 39 (29\%) \\
\hline & & Female & 41 & & 47 & & 9 & & & $97(71 \%)$ \\
\hline \multirow[t]{2}{*}{2} & \multirow{2}{*}{ Culex Spp. } & Male & 26 & \multirow{2}{*}{$\begin{array}{c}95 \\
(51 \%)\end{array}$} & 2 & \multirow{2}{*}{$\begin{array}{c}23 \\
(26 \%)\end{array}$} & 5 & \multirow{2}{*}{$\begin{array}{c}40 \\
(73 \%)\end{array}$} & \multirow{2}{*}{$\begin{array}{c}158 \\
(48 \%)\end{array}$} & 33 (21\%) \\
\hline & & Female & 69 & & 21 & & 35 & & & 125 (79\%) \\
\hline \multirow[t]{4}{*}{3} & \multirow{2}{*}{ Aedes Spp. } & Male & 9 & \multirow{2}{*}{$\begin{array}{c}22 \\
(12 \%)\end{array}$} & 2 & \multirow{2}{*}{$\begin{array}{c}9 \\
(10 \%)\end{array}$} & 1 & \multirow{2}{*}{$\begin{array}{c}5 \\
(9 \%)\end{array}$} & \multirow{2}{*}{$\begin{array}{c}36 \\
(11 \%)\end{array}$} & $12(33 \%)$ \\
\hline & & Female & 13 & & 7 & & 4 & & & $24(61 \%)$ \\
\hline & \multirow{2}{*}{ Total } & Male & 63 & \multirow{2}{*}{$\begin{array}{c}186 \\
(56 \%)\end{array}$} & 14 & \multirow{2}{*}{$\begin{array}{c}89 \\
(27 \%)\end{array}$} & 7 & \multirow{2}{*}{$\begin{array}{c}55 \\
(17 \%)\end{array}$} & \multirow{2}{*}{330} & $83(25 \%)$ \\
\hline & & Female & 123 & & 75 & & 48 & & & 246 (75\%) \\
\hline
\end{tabular}




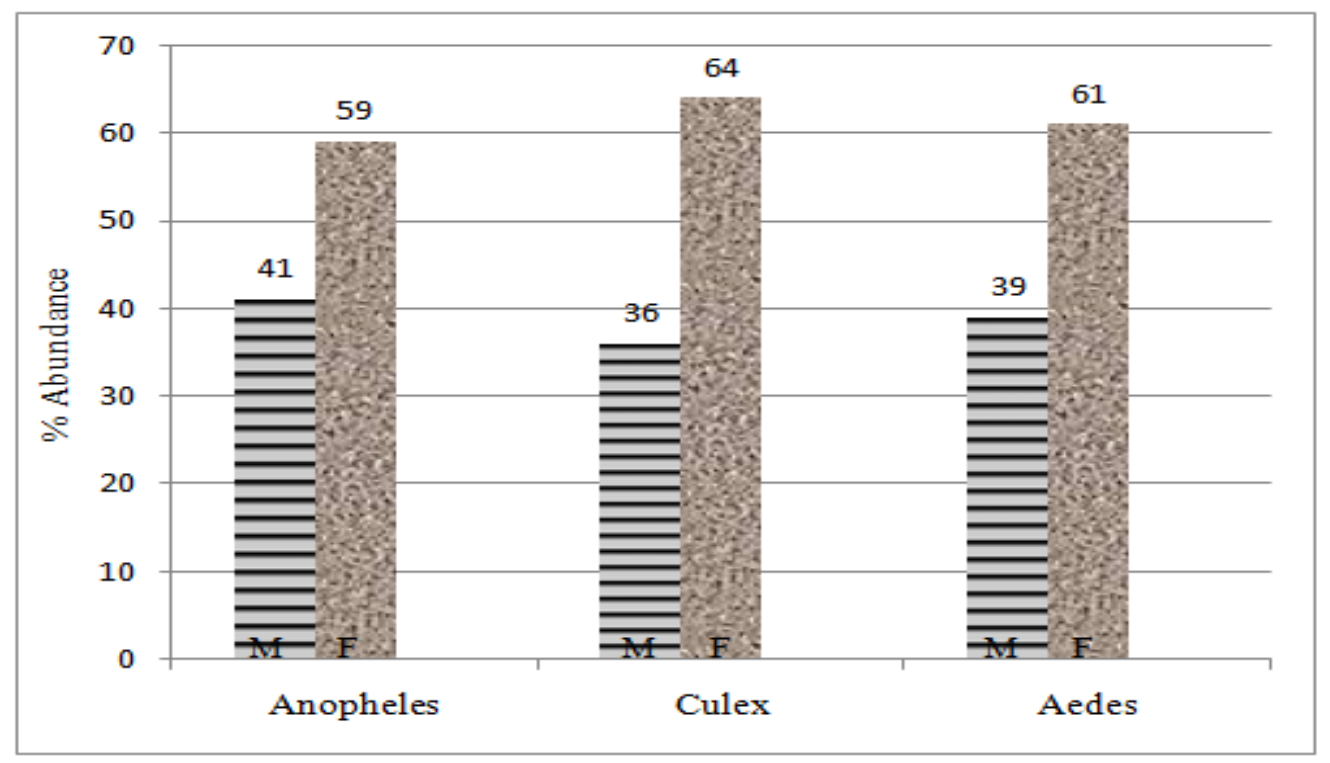

Figure 1. A multiple bar chart showing percentage abundance of mosquito sexes in stagnant water

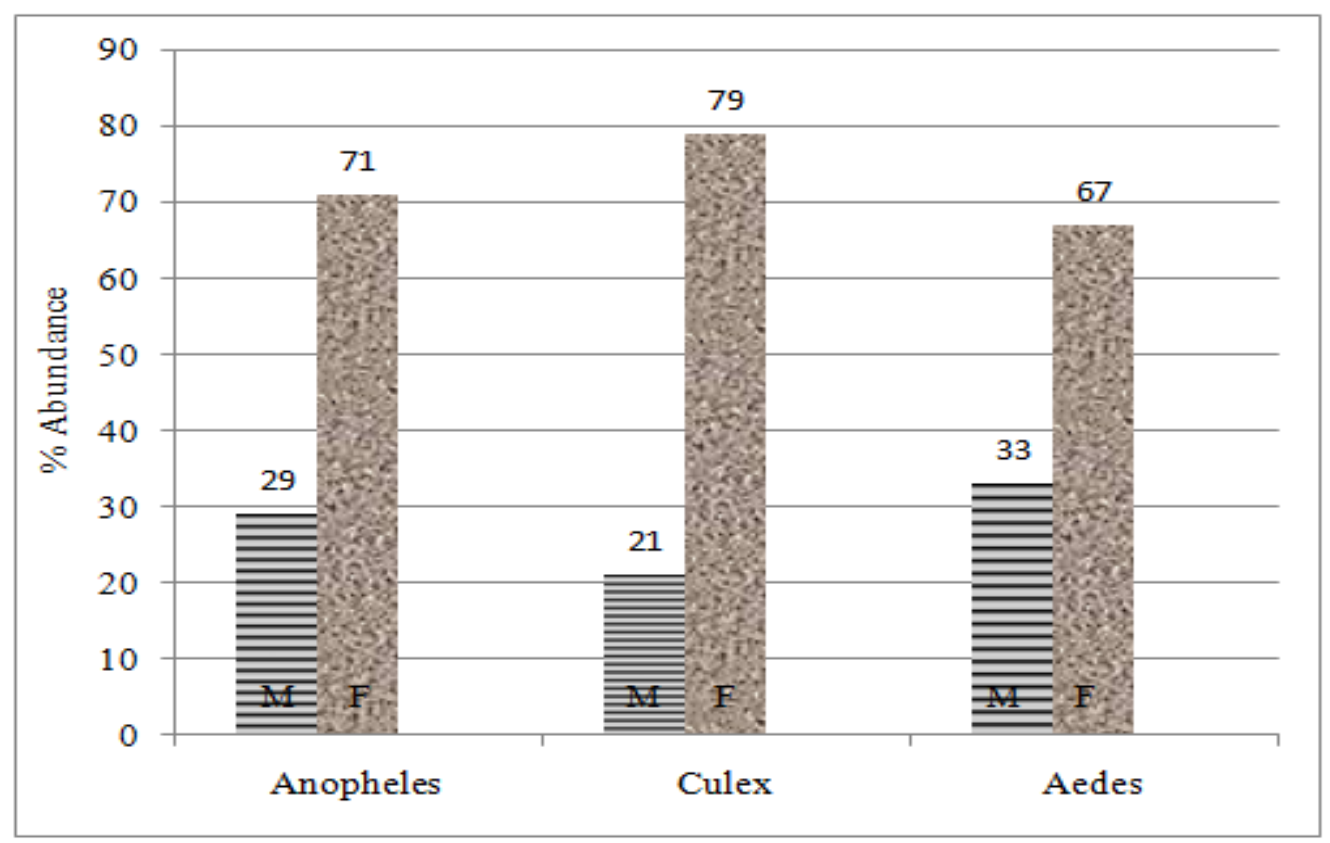

Figure 2. A multiple bar chart showing percentage abundance of mosquitoes in an induced container

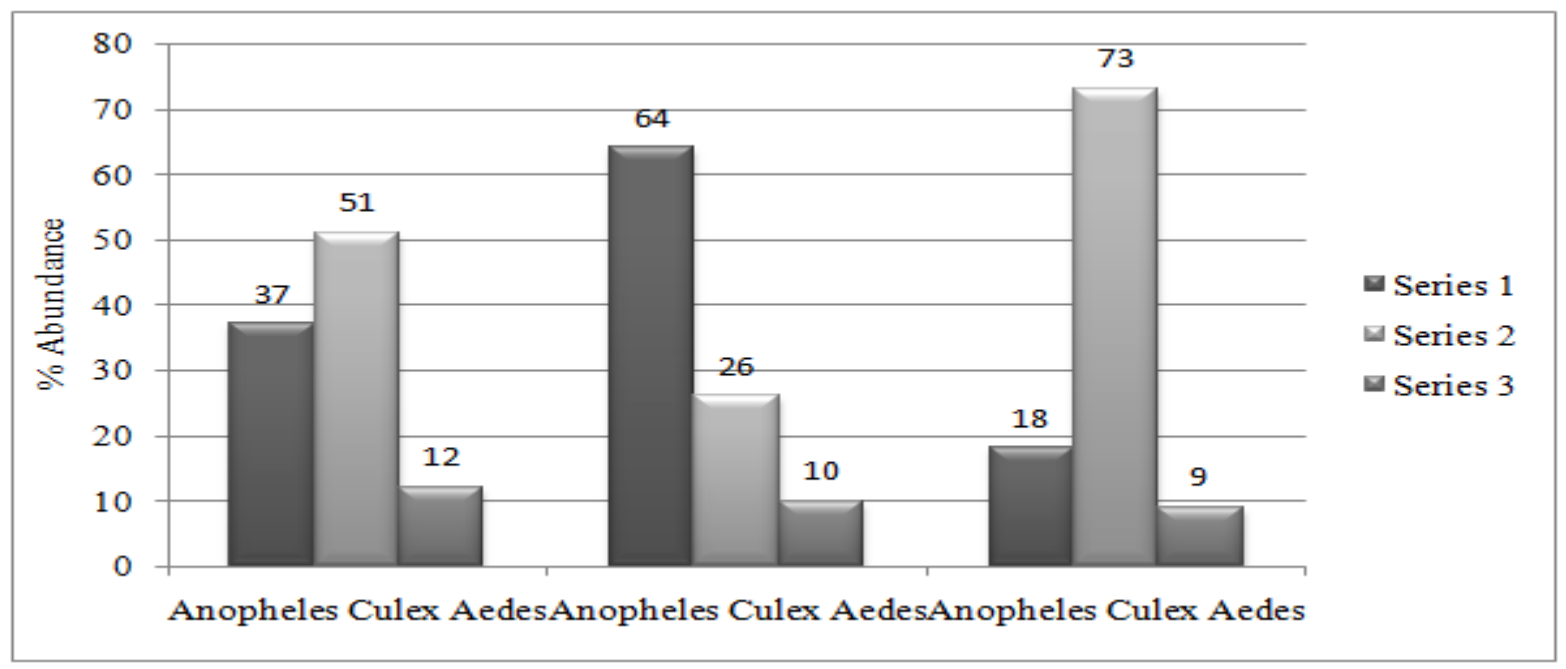

Figure 3. A multiple bar chart showing percentage abundance of mosquitoe species in three selected dumpsites of an induced container 


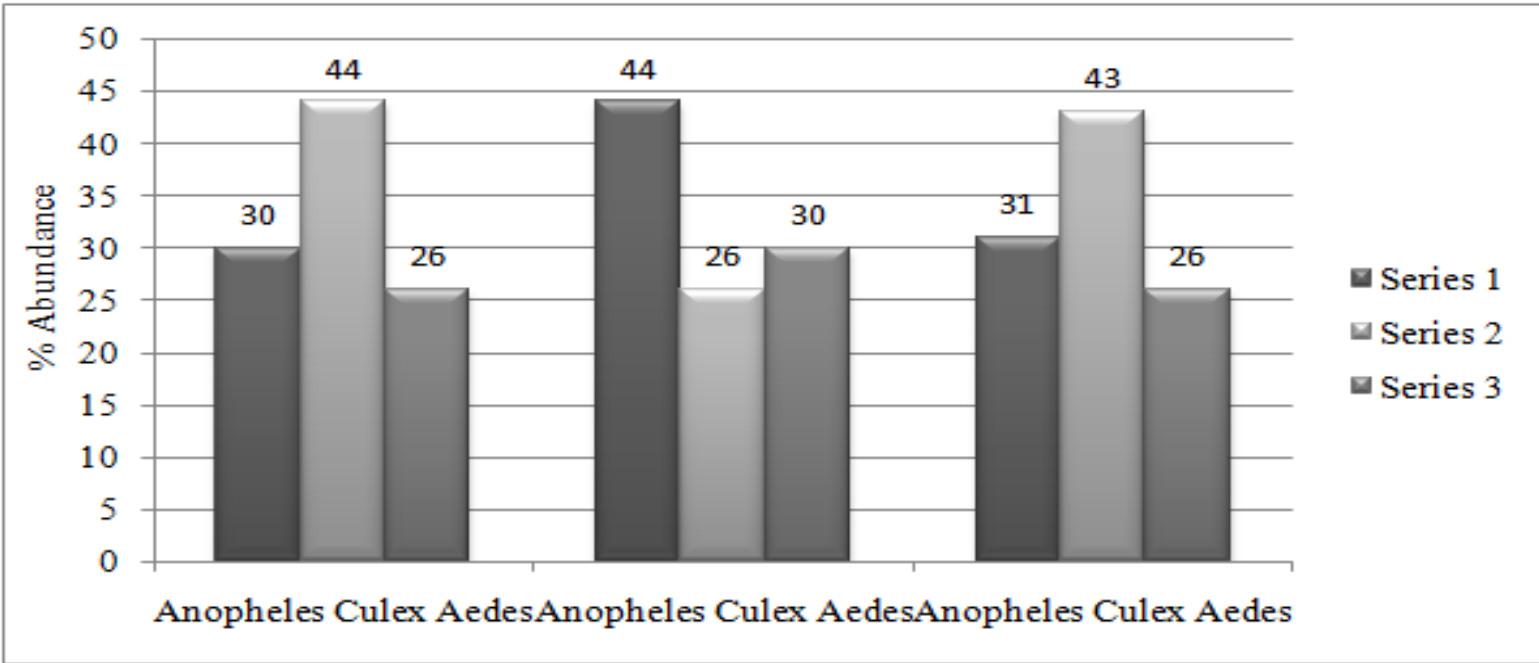

\section{Domestic dumpsite Mechanical Industrial dumpsite}

Figure 4. A multiple bar chart showing percentage abundance of mosquitoe species in three dumpsites of stagnant water
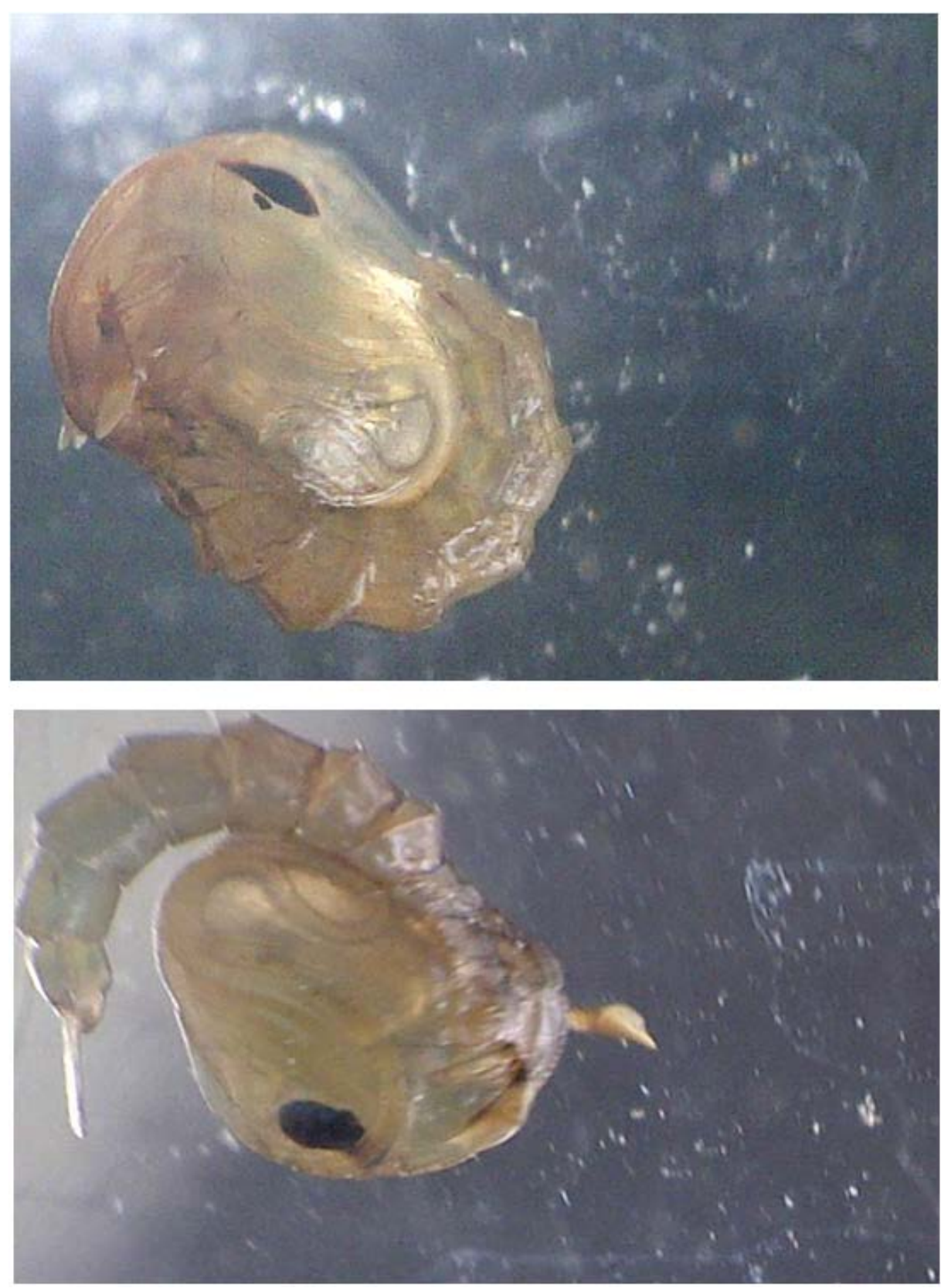

Plate 2. The photograph of sample mosquito pupas 


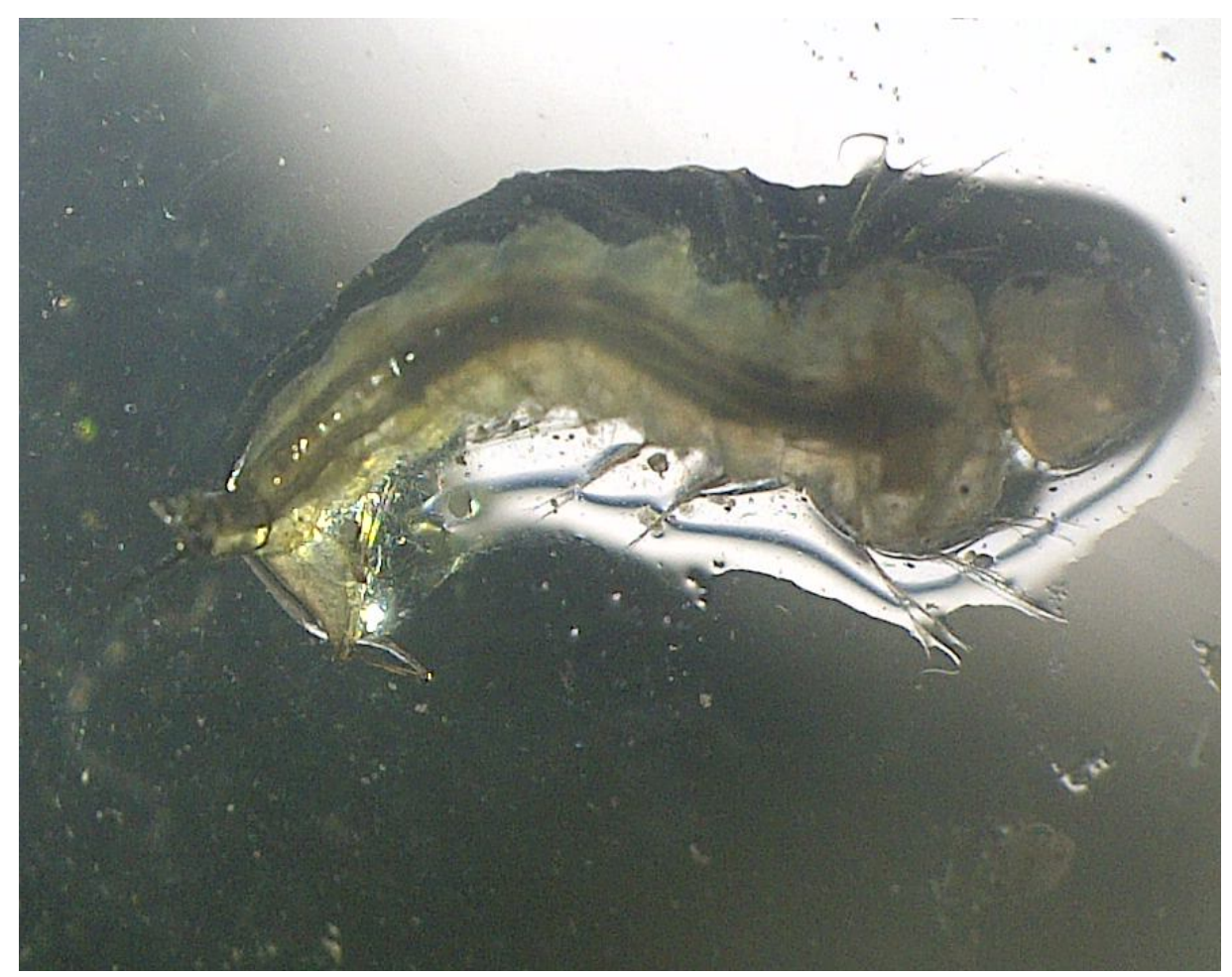

Plate 3. A Photograph of sample mosquito larvae

\section{Discussions}

The knowledge of habitat type where mosquitoes breed is very important so that such breeding sites are considered on priority basis for the effective control of their larvae [18]. The immature stages of mosquitoes are restricted to aquatic habitats as compared to the adult flying mosquitoes and can't escape readily from mosquito control technique [20].

The result of the survey showed that culex spp. had a higher preference to breed in domestic and industrial area. This is observed in their high abundance. Anopheles spp. was found to have high abundance in the mechanic dumping site due to the fact that, the dump site was very close to residential homes where waste water was always disposed [22]. In the other hand Aedes spp. was found to have the least abundance in the three studied area. Greater numbers of larva were found in stagnant water than that of the induced container and also the ration of female to male was 2:1.

This result was in agreement with the findings of Simon-Oke et al; [33] in Ekiti State, Nigeria. Although the authors observed that culex and Aedes have dominance in the area. On the contrary, Minakawa et al, [23] and Adeleke [4] in their findings on thespatial distribution and habitat characterization of Anopheline mosquito larvae in Western Kenya and Ikene, Ogun State, Nigeria repectively, observed that Anopheles was generally predominant. Likewise Adebote et al. [2] and Afolabi et al, [6] observed that Aedes mosquito was the most predominant in their findings in Zaria.

The abundance of culicine and anopheline mosquito species may be as a result of their ability to survive in diverse environment as previously reported by Dondorp et $a l$, [12]. The species richness of some of the mosquitoes suggest that the environment condition in these ecosystems were complex and favourable to support the continual breeding and survival of these vectors as also observed by Adeleke et al, [4].

The low population of Anopheles species caught in industrial dumping site and domestic dumping site may be due to the preference of the females to clear water for oviposition. Larvae of Anopheles preferred clear, fresh seepage water in sunlight or partially shaded pools [15]. The high abundance of culex in the two habitats is comparably in accordance with the findings of Usip and Ibanga [36] and contrast with the report of Onyido et al, [26].

\section{References}

[1] Abu, A. Hassan, M.R. Che salmah, j. Ngumbang, s. Ahmad Ramliand A. M. El-Badri. (2005) mosquitoes of urban areas of penang: Abundance and control. Vector control research unit, universiti sains malaysia, 11800 penang, malaysia.

[2] Adebote, D.A., Oniye SJ, Ndams IS and Nache KM (2006). The breeding of mosquitoes (Diptera: Culicidae) in peridomestic containers and implication in yellow fever transmission in villages around Zaria, Northern Nigeria. J. Entomol. 3(2): 180-188.

[3] Adebote, D.A., Oniye, S. J. and Muhammed, Y.A. (2008). Studies on mosquitoes breeding inrock pools on inselbergs around Zaria, Northern Nigeria. J. Vector Borne Diseases, 45:21-28.

[4] Adeleke, M.A., Mafiana CF, Idowu OA, and Sam Wobo SO. 2010 Population dynamics of indoor, sample mosquitoes and their implication in disease transmissionin Abeokuta, South Western Nigeria. Journal of vector Borne Disease, 47: 33-38.

[5] Afia, U. U. (2014) Occurrence and Numeric variations in species and sex distribution of Anopheles species in Malaria enteric communities of Akwa Ibom State. International Journal of advancement in Environmental Science. Vol. 10(1), pp 23-16.

[6] Afolabi, OJ, Ndams IS, Mbah CE, and Kogi E (2010). The effects of alteration of $\mathrm{pH}$ on the breeding characteristics of mosquitoes in phytotelmata in Ahmadu Bello University Zaria, Nigeria. Int. J. Bioscience. 5(1): 32-36.

[7] Aliyu, Mohammed Umar. (2014). Characterisation of Anopheles Mosquitoes, Breeding Sites And Retrospective Study Of Malaria In Katsina State, Nigeria. P: 1-201. 
[8] Amaechi, Ebube. C.; Ohaeri, Carmelita. C. and Ukpai, Onyinye. M (2014). Distribution and abundance of dry season indoor mosquitoes in a tropicalrural communityEgypt. Acad. J. Biolog. Sci., 7(1): 173-178 (2014).

[9] Clement, N. Mweya, Sharadhuli I. Kimera, Lesakit S. B. Mellau and Leonard E. G. Mboera. (2015). Inter-epidemic abundance and distribution of potentialmosquito vectors for Rift Valley fever virus in Ngorongoro district, Tanzania. Tukuyu Research Centre, National Institute for Medical Research, Tukuyu, Tanzania, Email: cmweya@nimr.or.tzGlob Health Action 2015, 8: 25929.

[10] David, L. Biassi, Carlos B. Marcondes, Glauber Wagner and Gerson A. Muller (2015). Mosquito species collected in a fragmented of the Atlantic forest bioma in the southern of Brazil.International Journal of Fauna and Biological Studies; 2 (2): 35-37.

[11] Desmond, H. Foley, Terry A. Klein, Heung Chul Kim, William J. Sames, Richard C. Wilkerson, and Leopoldo M. Rueda (2009). Geographic Distribution and Ecology of Potential Malaria Vectors inthe Republic of KoreaJ. Med. Entomol. 46(3): 680Đ692.

[12] Dondorp, A, Francois N, Poravuth Y, Debashish D, Aung P, Tarning J, Khin M, Ariey F, Hanpithakpong W, Lee S, Ringwald $\mathrm{P}$, Kamol rat S, Imwong N, Lindegardh N, Socheat D and White N. (2009). Artemisinin Resistance in Plasmodium Falciparum Malaria. New England Journal of Medicine 361 (5):455-467.

[13] Godwin, R.A. Okoguna, Jude C. Anosikeb, Anthony N. Okereb and Bethran E.B. Nwokeb. Ecology of mosquitoes of Midwestern Nigeria. J Vect Borne Dis 42, March 2005, pp 1-8.

[14] Godwin, R.A., Okoguna, Anosike, J.C., Okere, A.N. and Nwoke, B.E.B. (2005). Ecology of mosquitoes of Midwestern Nigeria. Journal of Vector Borne Diseases, 42: 1-8.

[15] Gouge, D.H, Smith KA, Olson C, and Baker P. (2001). Mosquitoes. The University of Arizona, College of Agriculture and Life Sciences, Tuscon, Arizona, 85721.

[16] Grillet M. E. (2000). Factors associated with distribution of Anopheles aquasalis and Anopheles oswaldoi (Diptera: Culicidae) in a malarious area, northeastern Venezuela. J Med Entomol 37: 231-238.

[17] Gul, Zamin Khan, Imtiaz Ali Khan, Inamullah Khan and Mian Inayatullah. (2014). Outdoor Breeding of Mosquito Species and its PotentialEpidemiological Implications in khyber pakhtunkhwa. Pakistan J. Agric. Res. Vol. 27 No.4.

[18] Ijumba, J.N, and Lindsay SW. (2001). Impact of irrigation on malaria in Africa: paddies paradox. Med Vet Entomol 1 5: 1-11.

[19] Junko, Yasuoka and Richard Levins (2007). Impact of deforestation and agricultural development on Anopheline ecology and malaria epidemiology. Am. J. Trop. Med. Hyg., 76(3), 2007, pp. 450-460.

[20] Killeen, GF, Fillinger F, and Knols GJ. (2012). Advantages of larvalcontrol for African malaria vectors Low mobility andbehavioural responsiveness of immature mosquito stagesallow high effective coverage. Malaria J 2012; 1:8.

[21] Martens P, 1998. Health and Climate Change: Modeling the Impacts of Global Warming and Ozone Depletion. London: Earthscan.

[22] Minakaw, N., Sonye, G., Mogi, M., Githeko, A., and Yan, G. (2002). The effects of climatefactors on the distribution and abundance of malaria vectors in Kenya. Journal Medical Entomology, 39: 833-841.

[23] Minakawa, N., C.M. Mutero, J.I.B Githure, J.I. Beier, and G. Yan. (1999). Spatial distribution and habitat characterization of
Anopheline mosquito larvae in Western Kenya. Am. J. Trop. Med. Hyg. 61(6): 1010-1016.

[24] Mirieri, Caroline Kwamboka.(2014). Effect of Controphic Species on Natural Population Dynamics of Malaria Mosquito Larvae on Rusinga Island.

[25] Molineux, L. (1998). The epidemiology of human malaria as an expression of its distribution including some implications for its control. Wernsdorfer WH, McGregor IA, Eds. Malaria, Principles and Practice of Malariology, Vol 2. London Churchill, Livingston, 913-998.

[26] Onyido, A.E., Agbata, V.O., Umeanaeto, P.U., Obiukwu M.O., and Amadi, E.S. (2010). MalariaBurden and Vector Abundance in a Sub-urban Community in the Rainforest Zone ofNigeria. Nigerian Journal of Microbiology, 24 (1): 2224-2230.

[27] Pattanayak, S. K., and Junko, Y. (2008). Deforestation and Malaria: Revisiting the Human Ecology Perspective. A Global Interdisciplinary Overview.

[28] Pattanayak, S.K., and J. Yasuoka. (2008). - Deforestation and Malaria: Revisiting the Human Ecology Perspective. In Human Health and Forests: A Global Overview of Issues Practice and Policy, edited by C.J.P. Colfer, 197-217. London: Earthscan Publishers.

[29] Rohi, Naz, Afsheen Maryam, and Shabnam. (2014) Population Dynamics of Mosquitoes in Various BreedingHabitats at University of Peshawar Campus, KhyberPukhtunkhwa Pakistan. Journal of Entomology and Zoology Studies 2014; 2 (2): 189-195.

[30] RydzaniczK. and LoncE. Species composition and seasonal dynamics of mosquito larvae in th Wroclaw, Poland area Journalof Vector Ecology 28 (2): 255-266. 2003.

[31] Saleeza. S.N.R., Norma-Rashid Y and M. Sofian-Azirun (2011). Mosquitoes Larval Breeding Habitat in Urban and Suburban Areas, Peninsular Malaysia. International Journal of Biological, Biomolecular, Agricultural, Food and Biotechnological Engineering Vol:5, No:10.

[32] Sharma, V.P. and DevV. (2014). Biology \& control of Anopheles culicifacies Giles. Indian J Med Res 141, May 2015, pp 525-536.

[33] Simon, Oke I.A, and Ayeni F.E. (2015) Relative abundance and composition of Endophilic Mosquitoes in federal university of technology Akure hostels, Ondo State, Nigeria. App. Sci. Report.10 (3), 2015: 133-136.

[34] Smith, KR, Corvalán, CF and T. Kjellstrom, 1999. "How Much Global Ill Health is Attributable to Environmental Factors?” Epidemiology 10: 573-584.

[35] Unicef, (2000). Promoting Rational Use of Drugs and Correct Case Management in Basic Health Services.

[36] Usip, L. P. E., and Ibanga, S. I. (2003). Identification of breeding sites and prevalence of endemicfoci mosquito vectors of parasitic infection in Uyo Urban, Akwa Ibom State, Nigeria. ActaZoologia Simica, 49 (4): 522-524.

[37] Wall, R. and Shearer, D. (2011). Veterinary Ectoparasites; Biology. Pathology and Control, $2^{\text {nd }}$ Edition, Blackwell Science Ltd, Uk, Pp262.

[38] Wilson, ME. (1995). "Infectious Diseases: An Ecological Perspective.” British Medical Journal, 311(7021): 1681-1684.

[39] Zita, Obi, Lucy Anyaegbunam and Oslar Emmy-Egbe. (2014). Human practices- a case in breeding of mosquitovectors in Ekwulobia, Anambra state Nigeria. Journal of Entomology and Zoology Studies 2014; 2 (4): 190-193. 